\title{
A HEURISTIC ALGORITHM FOR THE TRAVELING-SALESMAN PROBLEM
}

1. Procedure declaration. Let us denote by $G_{d}=\langle X, U ; d\rangle$ a network in which $G=\langle X, U\rangle$ is a complete graph (i.e., for all $x, y \in X$ we have $[x, y] \epsilon U)$ and $d$ is a real function $d: U \rightarrow R$.

A closed path passing through each node exactly once is called a $H a$ milton circuit of a graph G. Procedure TRAVEL finds the shortest Hamilton cycle in a symmetric $n$-node network.

Data:

$n$ - number of nodes of the network;

$P[1: n, 1: n]$ - symmetric array of distances between nodes of the network $(P[i, j] \geqslant 0)$;

$f h$ - integer number denoting the length of the route for a starting solution;

$R H[1: n]$ - array of node number of the starting solution.

Results :

$f h$ - integer number denoting the length of the route of a heuristic solution;

$R H[1: n]$ - array of node numbers of a heuristic solution.

Remark. The starting solution ought to be chosen in such a manner to make it possible to finish the calculations as quick as possible with the solution nearly optimal. The best situation is if we can use many starting solutions. From a few local optima found in this way we choose the best one (for example, the shortest or best in the relation to the configuration of the route). Different methods using starting solutions are described in [14].

2. Method used. In procedure TRA VEL a shortened version of the algorithm of Lin and Kernighan ([11] and [12]) has been used. This algorithm is a peculiar case of a general heuristic method used for solving: many optimization problems on a discrete set. 
integer procedure TRAVEL $(n, P, f h, R H)$;

yolue $n$;

integer $\mathrm{n}$, fh;

integer array $\mathrm{P}, \mathrm{RH}$;

\section{begin}

integer $a, a 1, a 2, b, b 1, b 2, g, g 0, g^{1}, g 2, g 3, g p, i, j, j 1, k, 1, m, p$, po, $\mathrm{p}^{1}, \mathrm{~s}, \mathrm{t}, \mathrm{z}, \mathrm{x}, \mathrm{y}, \mathrm{y}^{1}, \mathrm{y} 2$;

Boolean I1,I2,I3;

$\mathrm{m}:=\mathrm{n}-1$

begin

Integer arrex $K[1: n, 1: m], H, U[1: n], V, X[1: m], T[0: n+1]$;

Boolean procedure TOUR $(\mathrm{P}, \mathrm{H})$;

integer axrey $\mathrm{P}, \mathrm{H}$;

begin

integer $a, b, 1, j, k, 1, m, p, s$;

Boolean B;

$B:=$ folse;

s: $:=\mathrm{n}$;

$\mathrm{H}[1]:=1:=\mathrm{k}:=1:=\mathrm{m}:=1$;

I1: . for $j:=m$ atep 1 untid $k-1, k+1$ atep 1 until s de begin

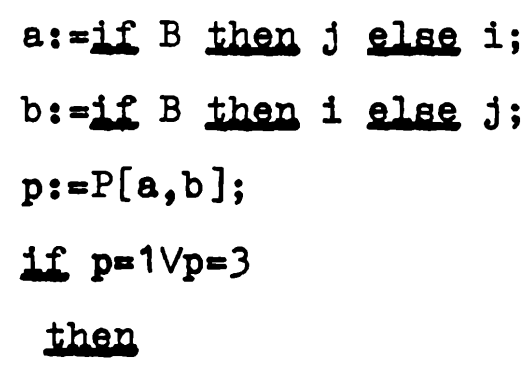


Algorithm 45

if $1 \neq n \wedge j \neq 1$

then

pegin

if $\mathrm{B}$

then

begin

$m:=j+1 ;$

$\mathrm{s}:=\mathrm{n}$

end $B$

else

begin

$m 8=1 ;$

B: $=\mathfrak{j}-1$

end not $B$;

$\mathrm{B}:=\boldsymbol{2} \mathrm{B}$;

go to I1

end $1 \neq n \wedge j \neq 1$;

TOUR \& =l=n;

eo to FINE

end $p=1 \vee p=3$

end $j$;

if $B$

then

bersin

$m:=i+1 ;$

$k:=i$;

$\mathrm{s}:=\mathrm{n}$

end $B$

else

begin 


$$
\begin{aligned}
& \mathrm{m}_{;}=\mathrm{s}:=1 ; \\
& \mathrm{k}:=1
\end{aligned}
$$

end not $B$;

$B:=\neg B$;

ge to L1;

FINE:

end TOUR;

for $k:=1$ sten 1 until $n$ de

begin

for $1:=1$ step 1 untid in de

$U[1]:=P[k, i]$;

for $1:=1$ step 1 until $m$ de

begin

$\mathrm{p}:=-1$;

$1:=n-1$;

for $j:=1$ sted 1 untid $n$ de

if $U[j]>p$

then

begin

$\mathrm{p}:=\mathrm{U}[\mathrm{j}]$;

$v[1]:=j$

end $U[j]>$ p, $j$;

$\mathrm{U}[\mathrm{V}[\mathrm{I}]]:=-1$

end $i$;

for $i:=1$ aten 1 untis in de

$K[k, 1]:=V[i]$

end $k$;

$\mathrm{z}:=0$;

ROT:

$T[0]:=\operatorname{RH}[n] ;$

$T[n+1]:=R H[1]$;

for $18=1$ step 1 untis $n$ de

$T[1]:=\mathrm{RH}[1]$;

$I 2$ : =f8.18e; 
PER\&

$28=2+1$;

Lor $1:=1$ sten 1 unttid $n$ do

if $T[1]=2$

then 80 to $\mathrm{E1}$;

$$
\begin{aligned}
\text { E1: } j: & =1-1 ; \\
1: & =n-j ;
\end{aligned}
$$

fer $k:=1$ aten 1 untel $n$ de

$\mathrm{H}[\mathrm{k}]:=\mathrm{T}[\mathrm{k}]$;

for $k:=1$ atep 1 until 1 de

$T[k]:=R H[k]:=H[1+k-1]$;

for $k:=1$ aten 1 untw of de

$T[1+k]:=R H[1+k]:=H[k]$;

$T[n+1]_{2}=T[1]$;

$T[0]_{2}=T[n]$;

for $1:=1$ step 1 untion $n$ de

fer $j:=1+1$ step 1 untid $n$ de

$P[1, j]:=0$;

for 1:=1 ateg 1 untid $n$ de

begin

$k:=T[1]$;

$I:=T[i+1]$;

if $k<1$

then $P[k, 1] s=1$

else $P[1, k]:=1$

end 1;

I1 : $=I 3$ : =f8]

$t:=2$;

$E: m:=T[2]$;

$a:=$ if $t<m$ then $t$ else $m$;

$b:=$ if $t>m$ then $t$ else $m$;

$x_{8}=P[b, a] ;$

$P[a, b]:=2$;

$X[1]:=m$;

$\dot{i}:=\mathrm{k}:=0$; 


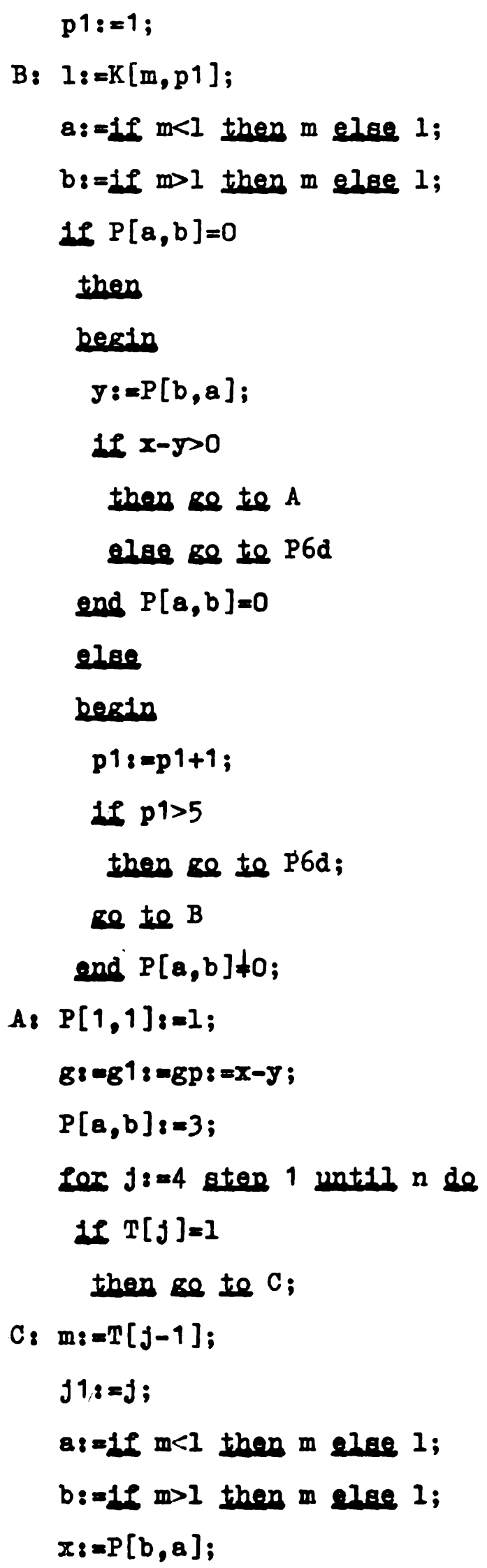


$P[a, b]:=2 ;$

$y 1:=P[$ if $m>t$ then in eise $t$, if $m<t$ then $m$ else $t$ ]:

$X[2]:=m$;

$83:=x-z 1 ;$

if $8^{1+8} 3>0$

then

hepetn

$80:=81+83 ;$

$k:=2$

and $81+83>0$

218e $808=0$;

$p:=1$;

A1: $1:=K[m, p]$;

$a_{8}=1 \mathrm{f} \mathrm{m}<1$ then $\mathrm{m}$ else 1 ;

$b_{8}=1 f m>1$ then $m$ else 1 ;

if $P[a, b]=0 \wedge I \$ t$

then $J \&=P[b, a]$

else.

beetin

$\mathrm{p}: \mathrm{p}+1 ;$

if $p>5$

then

berin

if $80>0$

then

beston

$a s=1$ if $m<t$ than in else $t$;

$b$ ind mpt then on elas $t$;

se to CB

and 80>0 


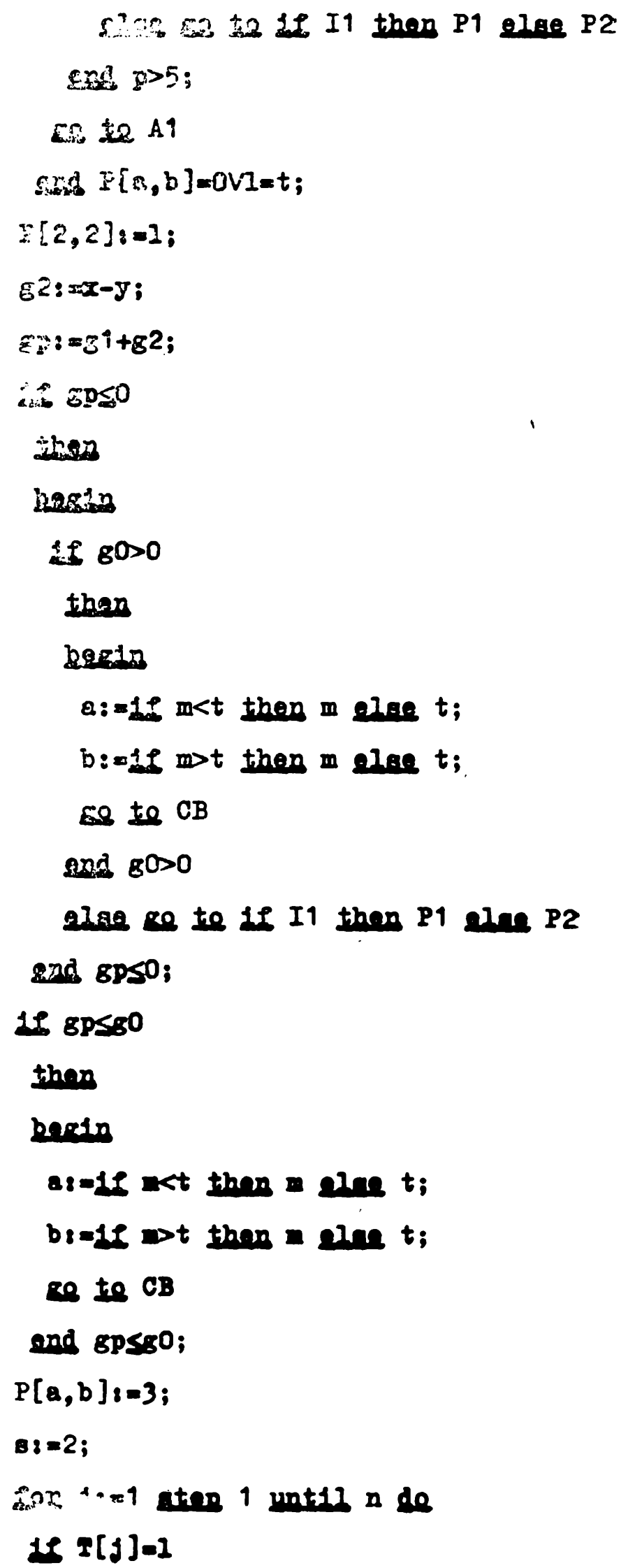


then 80 to B1;

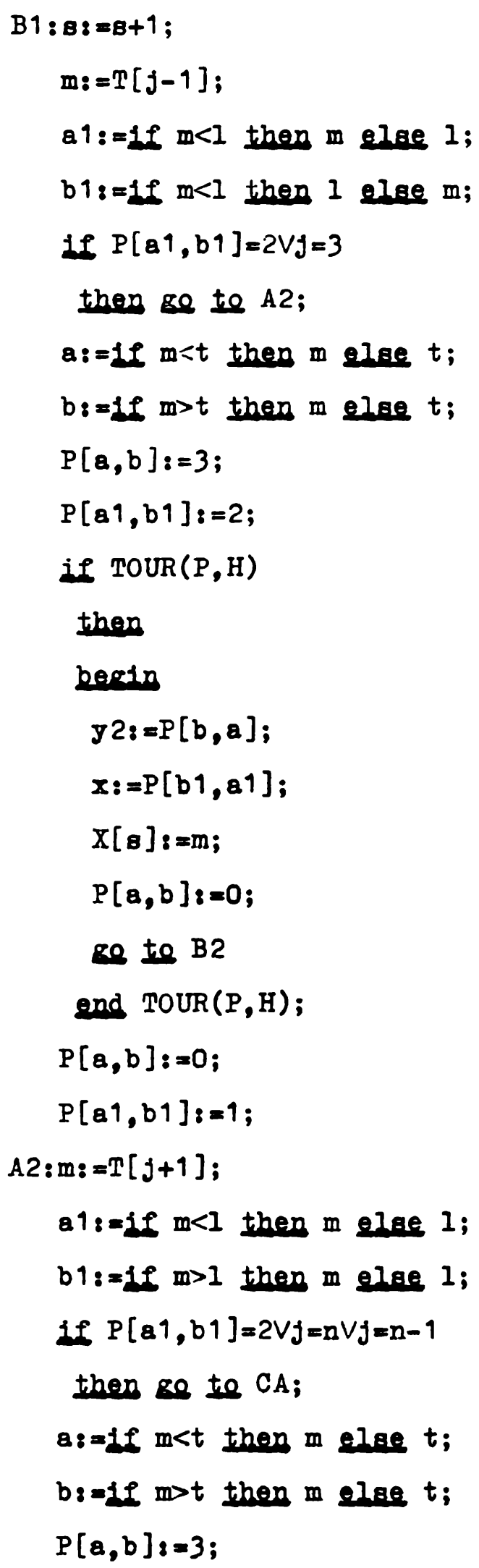




$$
\begin{aligned}
& P[a 1, b 1]:=2 ; \\
& \text { if } \operatorname{TOUR}(P, H) \\
& \text { then } \\
& \text { begin } \\
& y 2:=P[b, a] ; \\
& x:=P[b 1, a 1] ; \\
& X[B]:=m ; \\
& P[a, b]:=0 ; \\
& \text { ge to } B 2 \\
& \text { end } \operatorname{TOUR}(P, H) \\
& \text { else }
\end{aligned}
$$

begin

$$
\begin{aligned}
& P[a, b]:=0 ; \\
& P[a 1, b 1]:=1 ; \\
& \text { go to CA } \\
& \text { end TOUR }(P, H) ;
\end{aligned}
$$

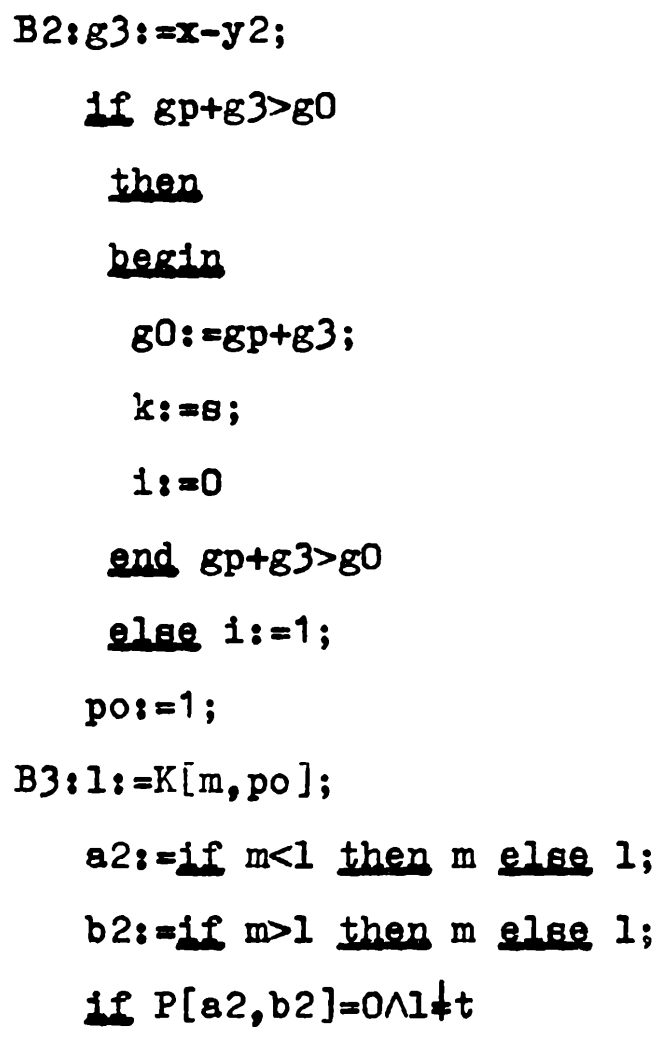


then $J:=P[b 2, a 2]$

else

begin

po: $=$ po+1;

if poses

then 20 to $\mathrm{CB}$;

ge to B3

end $P[82, b 2] \ddagger 0 V 1=t$;

$P[8,8]:=1$;

$\mathrm{g}:=\mathrm{x}-\mathrm{y}$;

$8 p:=8 p+8 ;$

if $g p \leq 0 \vee g p \leq g 0$

then go to $\mathrm{CB}$;

$P[a 2, b 2]:=3$;

for $j:=1$ ater 1 untid $n$ de

if $T[j]=1$

then se to B1;

$C A: I 3:=$ true;

$C B:$ if $z \geqslant n$

then ge to IOOP;

if $\mathrm{gO}>0$

then

begin

fh: $=f h-g 0$;

If $1=0$

then

becin

if I3

then

begin 


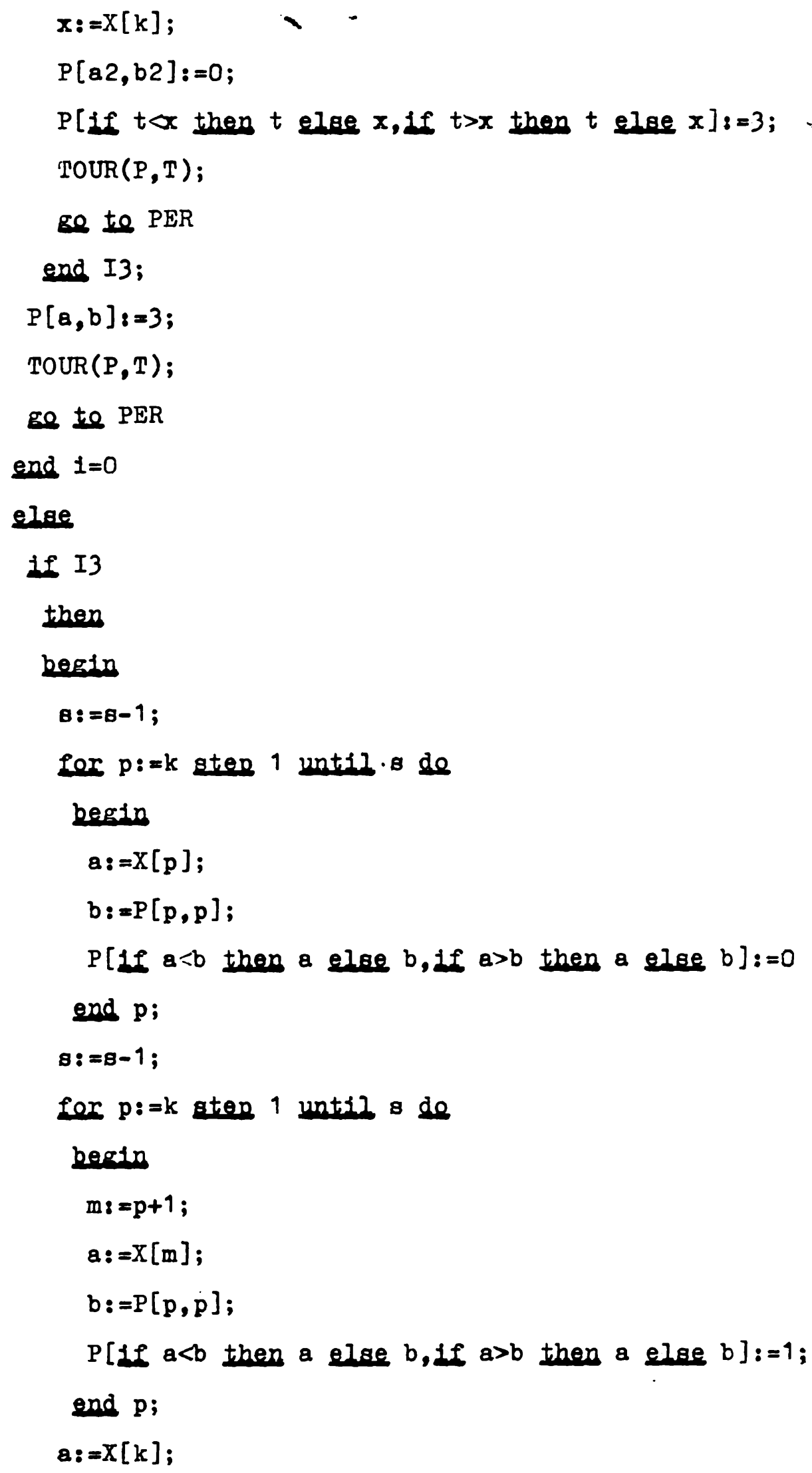




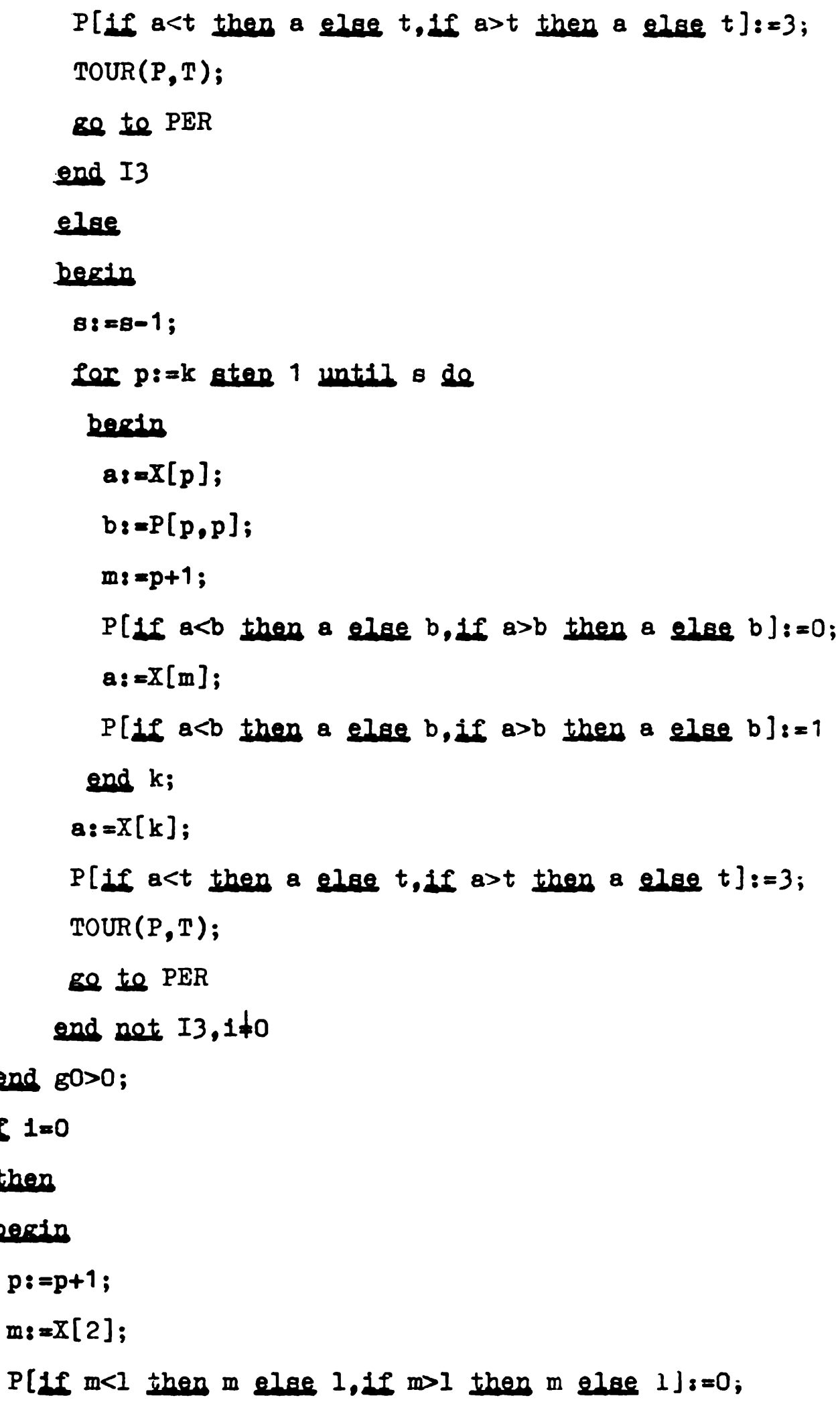


then se to if I1 then P1 else P2;

geo to $A 1$

end $1=0$

else.

iff I3

then

begin

$88=8-1 ;$

for pos=2 step 1 until a do

begin

$x_{8}=X[\mathrm{po}]$;

Y $8=\mathrm{P}[\mathrm{po}, \mathrm{po}]$;

$P[$ if $x<y$ then $x$ else $y$, if $x>y$ then $x$ else $y$ ] $=0$

end po;

$8:=8-1$;

for po: =2 gten 1 until a do

pering

$\mathrm{m}:=\mathrm{pot}$;

$x:=X[\mathrm{~m}]$;

$\mathrm{y}:=\mathrm{P}[\mathrm{po}, \mathrm{po}]$;

$P$ [if $x<y$ then $x$ else $y$, if $x>y$ then $x$ else $y$ ] $:=1$ end po;

$\mathrm{m:}=\mathrm{X}[2]$;

y: $=P[1,1]$;

$x:=P$ [if $m>y$ then $m$ else $y$, if $m<y$ then $m$ else $y$ ];

$\mathrm{p}:=\mathrm{p}+1$;

$I 38=f 8\}$ se;

if $p>5$

then 80 to if I1 then P1 else P2;

ge to A1 


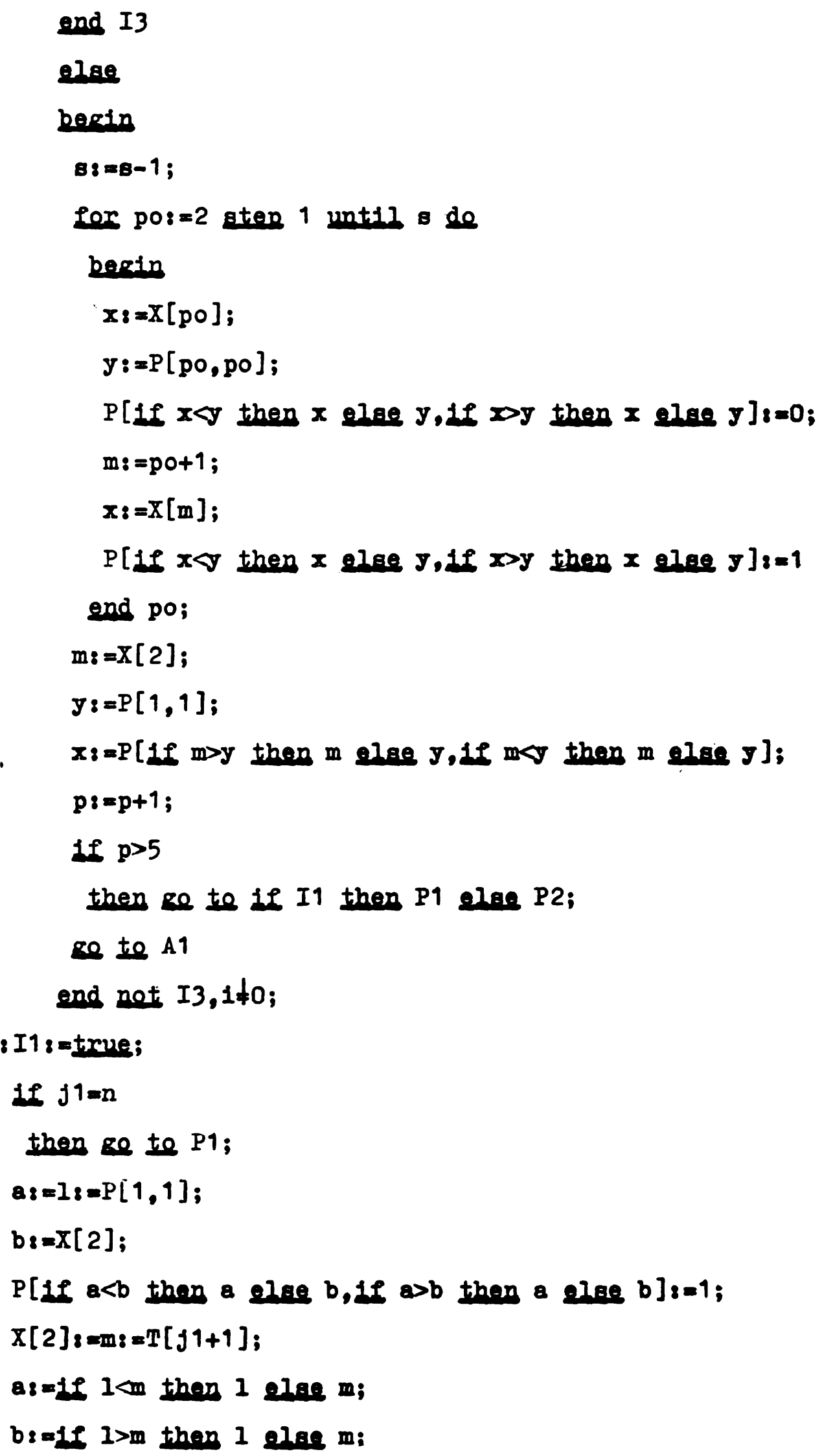




$$
\begin{aligned}
& x:=P[b, a] ; \\
& P[a, b]:=2 ; \\
& g p:=g^{1} ; \\
& \text { po: }=1 ;
\end{aligned}
$$

A1P2:

$1:=K[\mathrm{~m}, \mathrm{po}]$;

$a:=$ if $m<1$ then $m$ else 1 ;

$b:=1 f m>1$ then $m$ else 1;

if $P[a, b]=0 \wedge I \neq t$

then $y:=P[b, a]$

else

begin

po: $=$ po+1;

if $\mathrm{p} 0>5$

then go to P1;

ge to A1P2

end $P[a, b] \ddagger 0 V 1=t$;

$P[2,2]:=1$;

$\mathrm{g}:=\mathrm{x}-\mathrm{y}$;

$8 \mathrm{p}:=8 \mathrm{p}+\mathrm{g} ;$

if gp 50

then ge to P1;

$P[a, b]:=3$;

$8:=2$;

for $j:=1$ atep 1 until $n$ de

if $T[j]=1$

then go to B1P2;

B1P2:

if $j>j 1+1$

then se to B2P2 
else ge to B1;

B2P2:

$8:=8+1$;

$m_{8}=T[j-1] ;$

a 1: =if $1<\mathrm{m}$ then 1 else $m$;

b1:=if 1>m then 1 else $m$;

$\mathrm{P}[\mathrm{a} 1, \mathrm{~b} 1]_{\mathrm{z}}=2$;

$x_{8}=P\left[b 1, a_{1}\right]$;

$X[3]:=m$;

pos $=1:=1 ;$

A2P2:

$1:=\mathrm{K}[\mathrm{m}, \mathrm{po}]$;

for $j:=1$ atep 1 untid $n$ de

if $T[j]=1$

then se to A3P2;

A3P2:

if $j \geq j 1+1$

then

berein

pos $=p o+1$;

if po>5

then en to P11;

20 to $12 \mathrm{P2}$

and $y>f 1+1$;

$1 f 1+t$

then

becesp

82s =1f $m<1$ thon $m$ else 1 ;

b2s=if m then In else 1 ;

$J 8=P[b 2,82]$ 


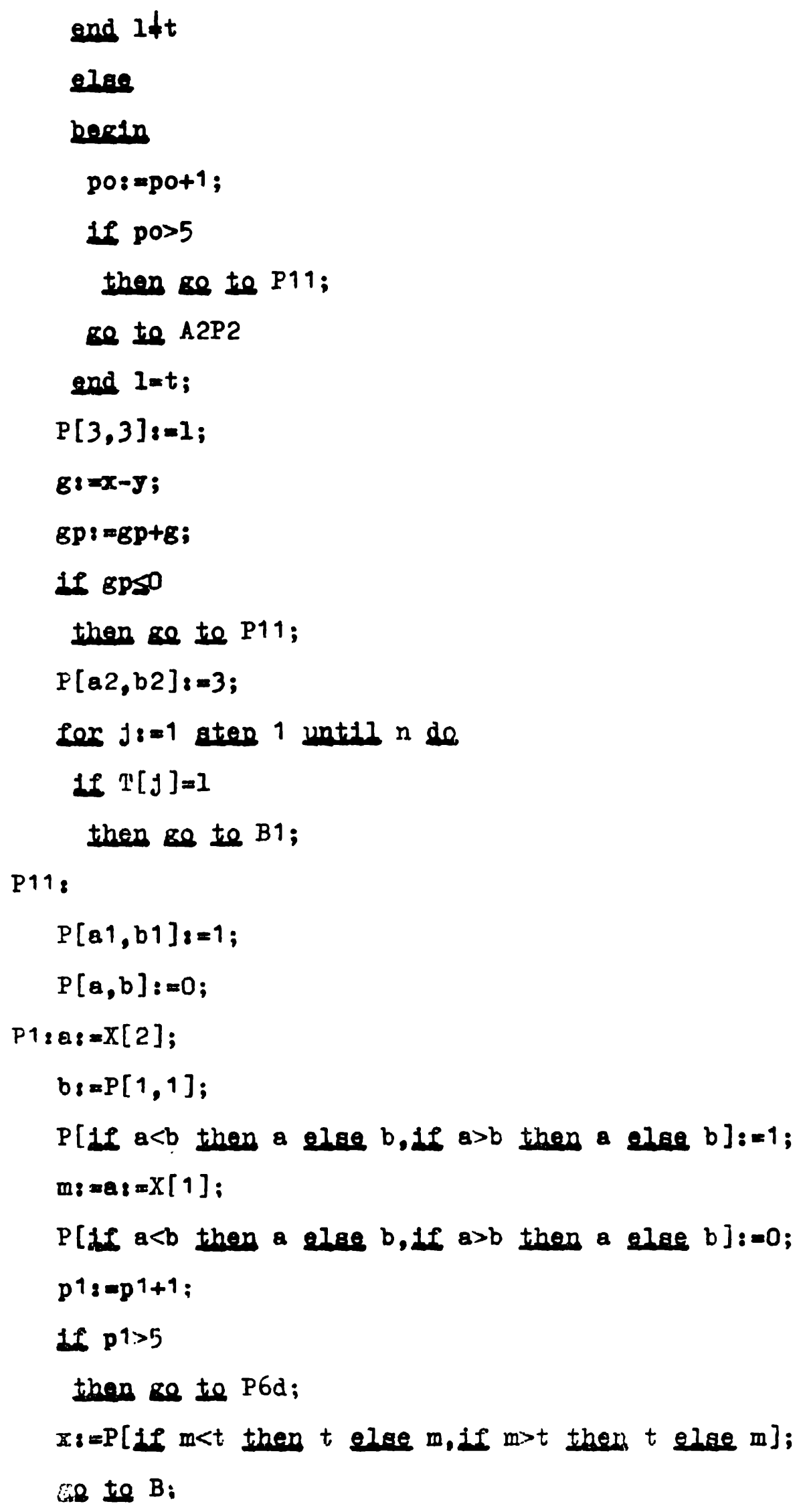


P6d:

if 12

then

begin

if $z=n$

then ge to IOOP;

go to ROT

end I2;

I2: =true;

$a:=t$;

$\mathrm{b}:=\mathrm{T}[2]$;

$P[$ if $a<b$ then $a$ elae $b$, if $a>b$ then $a$ else $b$ ] $:=1$; ,

$\mathrm{m}:=\mathrm{n}-1$;

for $1:=1$ aten 1 untid in do

$\mathrm{T}[i+1]:=\mathrm{RH}[\mathrm{n}-1+1]$;

$\mathrm{T}[0]:=\mathrm{T}[\mathrm{n}] ;$

go to E;

IOOP:

for $1:=1$ gten 1 untion $n$ de

$$
\mathrm{RH}[1]:=\mathrm{T}[1]
$$

end

end TRAVEL

The class of these problems can be formulated shortly as follows:

find a subset $T \subset S$ which satisfies some criteria $Z$ and minimizes the function $F$.

For example, a traveling-salesman problem can be formulated as follows:

from a set $U$ of all edges of a complete directed graph $G$ find a Hamilton circuit $H$ of minimal length.

Generally, the method mentioned above can be described by the following steps: 
1. Generate a pseudo-random solution $T$ satisfying some criterion $Z$.

2 . Improve the solution $T$ by some transformation.

3. If the found solution $T^{\prime}$ is better than $T$, i.e. if $F\left(T^{\prime}\right)<F(T)$, replace $T$ by $T^{\prime}$ and repeat from step 2 .

4. If no improved solution can be found, $T$ is a locally optimum solution. Repeat from step 1 until the computation time runs out or the answers are satisfactory.

The most important part of this procedure is the choice of the initial solution and transformation. The method of generation of the initial solution has been given in the Remark. In general, however, the transformation in step 2 relies on finding a number $k$ and sets

$$
\left\{x_{1}, x_{2}, \ldots, x_{k}\right\} \subset T \quad \text { and } \quad\left\{y_{1}, y_{2}, \ldots, y_{k}\right\} \subset S-T
$$

to be the best in the given iteration. These sets are generated "element by element", i.e. we choose $x_{1} \epsilon T$ and $y_{1} \in S-T$ as the "most-out-of-place". Then we choose elements $x_{2} \in T-\left\{x_{1}\right\}$ and $y_{2} \in S-T-\left\{y_{1}\right\}$ again in such a way that the replacement of $\left\{x_{1}, x_{2}\right\}$ by $\left\{y_{1}, y_{2}\right\}$ gives the greatest possible decrease of the Hamilton cycle length. We continue the process taking

TABI, 1

\begin{tabular}{|c|c|c|c|c|c|c|c|}
\hline Source of example & $\begin{array}{l}\text { Dimen- } \\
\text { sions of } \\
\text { problem }\end{array}$ & $\begin{array}{l}\text { Finding } \\
\text { starti } \\
\text { soluti } \\
\text { value of } \\
\text { object- } \\
\text { ive func- } \\
\text { tion }\end{array}$ & $\begin{array}{l}\text { the } \\
\text { ng } \\
\text { ons } \\
\text { time }\end{array}$ & 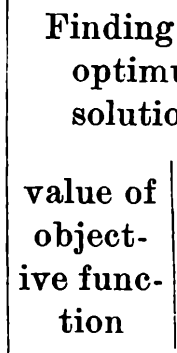 & $\begin{array}{l}\text { the } \\
\text { um } \\
\text { ns }\end{array}$ & $\begin{array}{l}\text { Frequen- } \\
\text { cy of } \\
\text { optimum } \\
\text { solution } \\
\text { occur- } \\
\text { rence }\end{array}$ & $\begin{array}{l}\text { Optimum } \\
\text { value of } \\
\text { objective } \\
\text { function }\end{array}$ \\
\hline Karg [8] & $\mathbf{5}$ & 148 & $\mathbf{l}$ & 148 & $\mathbf{l}$ & 1 & 148 \\
\hline Flood A [6] & $\mathbf{5}$ & 32 & 1 & 32 & 1 & 1 & 32 \\
\hline Flood B [6] & 6 & 22 & 4 & 22 & 2 & 1 & 22 \\
\hline Little [13] & 6 & 70 & 1 & 70 & 2 & 0.8 & 70 \\
\hline Dantzig [5] & 10 & 425 & 2 & 387 & 7 & 0.25 & 378 \\
\hline Christofides [2] & 10 & 229 & 2 & 212 & 6 & 1 & 212 \\
\hline Lawler and Wood [9] & 10 & 159 & 2 & 152 & 3 & 0.43 & 150 \\
\hline Croes [3] & 20 & 398 & 13 & 253 & 49 & 0.11 & 246 \\
\hline Held and Karp [7] & 25 & 1772 & 24 & 1711 & 162 & 0.42 & 1711 \\
\hline Polish cities $\left(^{1}\right)$ & 27 & 3901 & 30 & 3336 & 126 & 0.36 & 3336 \\
\hline Polish cities $\left({ }^{2}\right)$ & 27 & 4074 & 29 & 3757 & 121 & 0.5 & 3757 \\
\hline Karg [8] & 33 & 12218 & 53 & 10861 & 228 & & 10861 \\
\hline Dantzig [4] & 42 & 1591 & 123 & 1399 & 572 & & 1398 \\
\hline Held and Karp [7] & 48 & 13055 & 150 & 12294 & 1186 & & 11470 \\
\hline Karg [8] & 57 & 16538 & 236 & 13459 & 1741 & & 12955 \\
\hline
\end{tabular}


care that a possible replacement of $\left\{x_{1}, x_{2}, \ldots, x_{k}\right\}$ by $\left\{y_{1}, y_{2}, \ldots, y_{k}\right\}$. gives a solution that satisfies the criterion $Z$.

As is easily seen, the number $k$ may be different in each iteration.

3. Certification. Procedure TRAVEL has been verified on the ODRA 1204 computer for many examples found in the literature. The method of "the nearest neighbour with a starting point at the greatest gradient" [14] was used to obtain the starting solutions. The computational results. are listed in Table 1 (time in secs.).

It is seen from Table 1 that in most cases the optimum solution has been obtained by using only one starting solution. Optimum solutions. for almost all examples have been obtained when more random starting: solutions were used.

\section{References}

[1] M. Bellmore and G. L. Nemhauser, The traveling salesman problem (A survey), Opns. Res. 16 (1968), p. 538-558.

[2] N. Christofides, Bounds for the traveling-salesman problem, ibidem 20 (1972), p. 1044-1056.

[3] G. A. Croes, A method for solving traveling-salesman problem, ibidem 6 (1958), p. $791-812$.

[4] G. B. Dantzig, D. R. Fulkerson and S. M. Johnson, Solution of a large-scale traveling-salesman problem, ibidem 2 (1954), p. 393-410.

[5] - On a linear-programming, Combinatorial approach to the traveling-salesman. problem, ibidem 7 (1959), p. 58-66.

[6] M. M. Flood, The traveling-salesman problem, ibidem 4 (1956), p. 61-75.

[7] M. Held and R. M. Karp, A dynamic programming approach to sequencing. problems, J. Soc. Ind. Math. 10 (1962), p. 196-210.

[8] R. L. Karg and G. L. Thompson, A heuristic approach to solving traveling. salesman problems, Manag. Sci. 10 (1964), p. 225-248.

[9] E. L. Lawler and D. E. Wood, Branch-and-bound methods (A survey), Opns. Res. 14 (1966), p. 699-719.

[10] S. Lin, Computer solutions of the traveling-salesman problem, B.S.J. 44 (1965), p. $2245-2269$.

[11] - and B. W. Kernighan, A heuristic algorithm for the traveling salesman problem, Comp. Sci. Rep. 1 (1972), p. 1-40.

[12] - An effective heuristic algorithm for the traveling-salesman problem, Opns. Res. 21 (1973), p. 498-516.

[13] J. D. C. Little, K. G. Murty, D. W. Sweeney and C. Karel, An algorithm for the traveling-salesman problem, ibidem 11 (1963), p. 972-989.

[14] Z. Skupień and M. M. Sysło, Stosowana teoria grafów III. Grafy Eulera i Hamiltona. Zagadnienie komiwojazera, Matem. Stosow. (w druku).

INSTITUTE OF INFORMATICS

UNIVERSITY OF WROCEAW

50-384 WROCEAW

Received on 17. 1. 1975 


\section{HEURYSTYCZNY ALGORYTM DLA ZAGADNIENIA KOMI WOJAZ̈ERA}

\section{STRESZCZENIE}

Procedura TRA $\nabla E L$, oparta na metodzie Lina i Kernighana ([11] i [12]), po:szukuje możliwie najkrótszego cyklu Hamiltona w symetrycznej $n$-wezzłowej sieci.

Dane:

$n$ - liczba wierzchołków sieci;

$P[1: n, 1: n]$ - symetryczna tablica odległości między wierzchołkami sieci $(P[i, j] \geqslant 0)$;

$f h$ - liczba całkowita, oznaczająca długość drogi rozwiązania początkowego;

$R H[1: n]$ - tablica numerów wierzchołków rozwiązania początkowego.

Wyniki:

fl - liczba całkowita oznaczająca długoś drogi rozwiązania heurystycznego; $R H[1: n]$ - tablica numerów wierzchołków rozwį̨zania heurystycznego. W [14].

Uwaga. R6żne metody otrzymywania rozwiązania początkowego zawarte są

Obliczenia kontrolne, wykonane na maszynie cyfrowej ODRA 1204, nykazały poprawność procedury TRAVEL. W większości przykładów otrzymano rozwiązanie optymalne, startując $z$ jednego tylko rozwiązania początkowego. 